\title{
Greenhouse Tomato Producers' Views on Soilless Agriculture in Antalya ${ }^{\#}$
}

\author{
Bilge Gözener*, Halime Dereli
}

Department of Agricultural Economics, Faculty of Agriculture, Gaziosmanpaşa University, 60240 Tokat, Türkiye

A R T I C L E I N F O
"This manuscript has been presented in the
"I.International Academic Research
Congress"

\section{Research Article}

Received 20 December 2017

Accepted 13 March 2018

Keywords:

Tomato

Greenhouse

Antalya

Soilless agriculture

*Corresponding Author:

E-mail: bilge.gozener@gop.edu.tr \begin{abstract}
A B S T R A C T
Tomato comes as the most commonly produced, consumed and subject for trading in the world. Alongside fresh consumption, on the other hand it forms the most significant raw material source of food industry, especially for tomato paste, frozen and dried vegetablefruit and canned food industry. Turkey's greenhouse vegetable production field for 2016 year is 675173 decars and Antalya forms $51 \%$ of this field. Tomato forms $61.72 \%$ of Antalya's greenhouse production. The main material of the research consists of interviews made with producers resided in 5 villages/towns, where greenhouse tomato production is carried out densely in Antalya city, Alanya district. In 48 villages and towns, greenhouse tomato production is carried out, according to the official records. In the chosen areas, 365 producers exist. $20 \%$ of these producers (73) form the sample size. In the research, it was determined that the producers' average agricultural land possession is 9.13 decars and in $40.53 \%$ of these areas they grew tomatoes. None of these producers are engaged in contractual growing. All of the yield is produced for the edible (as table-top item). After the harvest, all of the products are sold in the wholesales market in county and city. $7.89 \%$ of the producers have no information on soilless agriculture, as $10.52 \%$ of them think that it has no advantages and $73.36 \%$ of them recommend traditional agriculture.
\end{abstract}

DOI: https://doi.org/10.24925/turjaf.v6i4.460-463.1764

\section{Introduction}

Greenhouse agriculture, which requires high plant and operational costs compared to other agricultural branches, is a form of enterprise that requires more technical knowledge and skill and continuous and more demanding work (Pezikoğlu, 1999), allows for the assessment of small areas and high efficiency from the unit level; particularly concentrated in the southern coast of Turkey. The 2016 greenhouse vegetable production area is 675173 decares and the tomato constitutes $50 \%$ of this area in Turkey. $51 \%$ of the greenhouse vegetable production area in Turkey is realized in Antalya (Anonymous, 2016a, Anonymous 2016b).

The monoculture applied to the greenhouses causes various problems, such as productivity and quality reductions that restrict production (soil-borne diseases and pests increase and soil fatigue). New methods have been sought to remove these problems (Gül et al., 1998) and as an alternative application, landless agriculture has come to the agenda (Gül et al., 1998, Van Os et al., 2000, Tüzel and Özçelik, 2004).

Soil-free agriculture with a general definition is the realization of all types of agricultural production in solid or liquid growing environments enriched with plant nutrients besides soil (Sevgican, 1999). The goal of landless agriculture, which has been applied in greenhouse cultivation but has recently been applied openly, is to provide the growth of plants with nutrient solution and to provide the nutrients and water requirements of the plants economically in water or solid environment enriched with nutrient solutions.

First application in large scale in soilless agriculture is during The World War II, the production of vegetables for the soldiers in the Pacific Ocean, carried out by the American army in water and gravel. After 1970s, commercial applications became widespread (Anonymous, 2014).

In many countries in the world, landless plant growing is being carried out and a total of 31,000 hectares of soilless agricultural land is reported to be present. Especially in the Netherlands, $80-90 \%$ of greenhouse vegetable cultivation is carried out with landless agriculture (Anonymous, 2008).

Soilless agriculture applications have also become increasingly common despite the fertile agricultural areas in Turkey.

Commercial sense to use hydroponics in Turkey began in Antalya in the 1990s. It is estimated that 20 hectares of landless farming in 2000, has reached out to 145 hectares as of 2008 and 3000 hectares as of 2013. Soilless agriculture, which is a very limited area (about $0.4 \%$ ) compared to the total greenhouse area, is common in the Mediterranean and Aegean regions and constitutes $74 \%$ of total production in Antalya and İzmir provinces (Anonymous, 2013). 
It was aimed to consider and evaluate the situations in which producers would consider using this new production technique in this research, which was recently applied and which is devoted to producers' thinking about landless agriculture, which is a new form of production. With regard to soilless agriculture production, a number of researches have been made using various techniques, although not so many. These researches address the issue from different perspectives. In this research, the producers' thoughts on landless agriculture were included.

\section{Materials and Methods}

The main material of the study is the questionnaires made with the producers of 5 villages / towns where the production of greenhouse tomatoes is concentrated in Antalya province of Alanya. It has been determined from official records that 48 villages and towns in the province of Alanya have raised greenhouse tomatoes. From these 48 villages, 5 villages/municipalities (Emişbeleni, Telatiye, Türkler, Toslak and Payallar) were objective sampling methods selected. There are a total of 365 producers in the selected regions. Since it is difficult to go to these 5 villages and survey with 365 producers (73), $20 \%$ of the producers have been interviewed considering that they would represent the population. The surveys were carried out in March 2017. The data obtained in the research were transferred to tables and interpreted.

\section{Research Findings}

When the ages of producers participating in the survey are examined, it is determined that $12.33 \%$ of the producers are under 30 years old, $41.09 \%$ of them are 46 years old and above and $46.57 \%$ of them are between 31 45 years old. The average age of the producers is 43.36 . $95.89 \%$ of the producers are male individuals. When the educational status of producers is examined, it is determined that $73,08 \%$ producers are primary school graduates while middle school graduates have a percentage of $12,33 \%$ and high school graduates have $9,59 \%$. On average $\% 9,13$ are agricultural areas, 40,53\% have tomatoes while different crops are grown in the remaining area.
It has been determined that these producers who have grown tomatoes for an average of 18 years have an annual agricultural income of $42146.5 \mathrm{TL}$ and $80.25 \%$ of this income comes from tomato cultivation.

Some of the producers $(8,22 \%)$ rent the land and farm, while $94,52 \%$ use their own land. $97.44 \%$ of the producers obtain seedlings from the dealers.

The low incidence of workmanship and the high incidence of production are the main reasons for producers to grow tomatoes (Table 1). In addition to this, less labor reduces the cost and increases the price. These are also effective factors for tomato cultivation.

Producers do not engage in contractual cultivation due to $5.48 \%$ of them not knowing, $8.22 \%$ not hearing about it, $84.93 \%$ not needing it and $1.37 \%$ of them having different reasons.

As in all production branches, producers face a number of problems during the production phase in tomato growing. Some of the issues identified by producers are given in Table 2.

It has been determined that the most important problem faced by producers is diseases and pests. Apart from this, high input prices are also included in the problems that affect tomato producers significantly. The low number of producers indicating that they have problems with price and labor force supports Table 1. $84.93 \%$ of the producers stated that they were receiving training for production and they participated in these trainings on an average of 3 times.

Only $38.36 \%$ of the producers used loans or incentives in greenhouse construction and $83.56 \%$ said that the support given to the producers was insufficient.

It was determined that only $8.22 \%$ of the producers who participated in the survey had agricultural product insurance and the rest did not have insurance due to the fact that they did not need it $(89.55 \%)$ or found that the conditions were heavy $(10.45 \%) .45 .20 \%$ of the producers had an average of 2 soil analysis but $78.79 \%$ adapted to the recommendations of the analysis. Taking into account the results of the analysis, more than half $(57.69 \%)$ of the tomato producers stated that there was no difference in the production. It was determined that the producers did not perform soil analysis due to the reasons that they did not care about it $(80.00 \%)$, did not need it $(12.50 \%)$ and other $(7.50 \%)$.

Table 1 Farmers' reasons for tomato cultivation

\begin{tabular}{l|cc}
\hline \multicolumn{1}{c|}{ Reasons } & Frequency & Percentage \\
\hline High price & 10 & 13.69 \\
High income & 42 & 57.53 \\
Low cost & 7 & 9.59 \\
Less workmanship & 50 & 68.49 \\
\hline
\end{tabular}

Table 2 Problems encountered by producers in tomato production

\begin{tabular}{l|cc}
\multicolumn{1}{c|}{ Problems } & Frequency & Percentage \\
\hline Expensive input & 35 & 47.95 \\
Missing technical information & 3 & 4.11 \\
Insufficient workforce & 2 & 2.74 \\
Disease-pest & 59 & 80.82 \\
Low price & 16 & 21.92 \\
\hline
\end{tabular}


Table 3 Producers' thoughts on landless agriculture

\begin{tabular}{|c|c|c|c|}
\hline Thoughts & Answers & Frequency & Percentage \\
\hline \multirow{3}{*}{$\begin{array}{l}\text { Hearing about soilless agriculture production or } \\
\text { not }\end{array}$} & Yes & 38 & 52.05 \\
\hline & No & 35 & 47.95 \\
\hline & Total & 73 & 100 \\
\hline \multirow{3}{*}{ Information source on soilless agriculture * } & From the village & 34 & 89.47 \\
\hline & From the fair & 4 & 10.53 \\
\hline & Internet-television & 3 & 7.90 \\
\hline \multirow{5}{*}{$\begin{array}{l}\text { Farmers' personal thoughts on landless } \\
\text { agriculture* }\end{array}$} & I have no knowledge & 3 & 7.89 \\
\hline & More dangerous than traditional & 4 & 10.53 \\
\hline & Production is made without soil & 14 & 36.84 \\
\hline & It's organic & 16 & 42.11 \\
\hline & Production is continuous & 6 & 15.79 \\
\hline \multirow{7}{*}{$\begin{array}{l}\text { Reasons for producers to find landless } \\
\text { agriculture advantageous } *\end{array}$} & Being disease-free & 2 & 5.26 \\
\hline & Continuous production & 11 & 28.95 \\
\hline & Organic sale & 13 & 34.21 \\
\hline & Marketing convenience & 2 & 5.26 \\
\hline & Quality product & 10 & 26.32 \\
\hline & Selling more products & 3 & 7.89 \\
\hline & No advantage & 4 & 10.53 \\
\hline \multirow{5}{*}{$\begin{array}{l}\text { Reasons for producers to find landless } \\
\text { agriculture disadvantegous* }\end{array}$} & It is unhealthy & 6 & 15.79 \\
\hline & High cost & 15 & 39.47 \\
\hline & No difference in sales price & 5 & 13.16 \\
\hline & Residual excess & 13 & 34.21 \\
\hline & More fertilizer use & 4 & 10.53 \\
\hline \multirow{2}{*}{ Consideration of doing soilless agriculture } & Considering & 7 & 18.42 \\
\hline & Not considering & 31 & 81.58 \\
\hline \multirow{2}{*}{$\begin{array}{l}\text { The reason to consider doing soilless } \\
\text { agriculture production * }\end{array}$} & Quality product & 7 & 100.00 \\
\hline & Climate control & 2 & 28.57 \\
\hline \multirow{3}{*}{$\begin{array}{l}\text { The reason to not consider doing soilless } \\
\text { agriculture production * }\end{array}$} & Cost & 19 & 61.29 \\
\hline & Workforce & 13 & 41.94 \\
\hline & It is unhealthy & 4 & 12.90 \\
\hline
\end{tabular}

*More than one option marked

Table 4 Cost element considered to be the highest

\begin{tabular}{l|cc}
\hline \multicolumn{1}{c|}{ Cost element } & Frequency & Percentage \\
\hline Workforce & 15 & 39.47 \\
Fertilizer & 8 & 21.05 \\
Facility & 14 & 36.84 \\
Energy & 10 & 26.32 \\
\hline
\end{tabular}

Table 5 Reasons for producers to recommend traditional agriculture

\begin{tabular}{l|cc}
\hline \multicolumn{1}{c|}{ Reasons } & Frequency & Percentage \\
\hline Installation cost is low & 12 & 42.86 \\
It is healthier & 5 & 17.86 \\
Drug residues are less & 10 & 35.71 \\
Workforce advantage & 5 & 17.86 \\
Turkey's rich soil & 6 & 21.43 \\
Total & 38 & 100 \\
\hline
\end{tabular}

The opinions of producers of tomato cultivation in the study area on landless agriculture are given in Table 3.

From the producers participating in the survey, the ratio of those who heard of landless agriculture and those who did not are pretty close to each other. A significant number of producers who have heard of soilless agriculture have expressed their appreciation for the concept of soilless agriculture due to the landless farming in their villages. The producers have different thoughts about this production method they have just heard of. The fact that the grown crops are organic and the production is not dependent on the soil is at the beginning of these considerations. The producers have pointed out that the benefits of soilless agriculture in terms of organic, quality, continuous production and several similar reasons have different disadvantages, especially in terms of cost and excess of drug residues.

Only $18.42 \%$ of those who have heard of the concept of soilless agriculture are considering doing soilless agriculture with the thought that they will get quality 
products. High cost $(39.47 \%)$ comes on top of the reasons why producers do not consider landless agriculture. Many items are included in production cost.

The producers point out different inputs as the highest cost item in the case of production with landless agriculture. The relevant data are given in Table 4. Some producers find labor costs to be the highest expenditure items while some say the same for facility costs amd some say the same for fertilizer and energy costs.

A significant number of producers $(73.68 \%)$ stated that they would recommend traditional farming to a new breed of farming. The reasons for recommending traditional agriculture are given in Table 5.

It has been determined that the producers recommend traditional farming to new producers for different reasons, especially for low cost of installation and less drug residue in crops.

The rate of farmers recommending landless farming is $26.32 \%$, due to the reasons of high organic yield $(70,00 \%)$ and high yield $(30,00 \%)$.

\section{Conclusion}

Tomato, which has a great place in the Turkey's agriculture and economy, is one of the important income sources of our farmers. The province of Antalya is a region that is wet with rains in the middle of the winters and hot and humid in the summers in terms of climatic conditions and environmental conditions. Many vegetables are grown in the province of Antalya which has fertile lands. Tomato is one of the most produced vegetables among other grown vegetables. It is an important source of income for producers in Alanya province, which is a research region, due to the reasons as well as domestic consumption and exportation. Tomato production in the province of Antalya is carried out in greenhouses during 9 months of the year. Production is predominantly based on conventional methods. Although the number of young farmers is low and the educational status is low, it has been determined that farmers are very experienced in production. The producers usually grow tomatoes in half of the existing area and different crops in the other half. However, they provide the majority of their income from tomato. It is noteworthy that even though the use of credit or incentives is low, the credit and incentives provided are found inadequate by the producers.

Since the level of damage from natural disasters in the research area is very low, very few farmers have agricultural product insurance. However, the people of the region, who rarely encounter these disasters, suffer a great loss. From this point of view, the producers need to be made aware of insurance.
The biggest problem in production is diseases and pests. Training can be done to increase productivity and reduce costs of spraying. It will be in favor of the producers that do not engage in contractual cultivation without disclosing any reason to be informed about contractual cultivation. Despite the existence of a business that engages in soilless agriculture in the research area, the fact that nearly half of the producers not hearing about soilless agriculture can be interpreted into that they do not follow and worry about innovations related to their works. The fact that producers who have heard of soilless agriculture have not had a full knowledge of the subject and a great majority of them not wanting to try landless agriculture shows that they are not told and taught about the subject and this is why publishing studies are necessary.

\section{References}

Anonymous. 2008. Ministry of Agriculture and Rural Affairs, Global Warming and Country Agriculture Series. [ Accessed: 15.12.2017]

Anonymous. 2013. West Mediterranean Agricultural Research Institute Directorate (BATEM), Notes on Investigations on Soilless Agriculture. [Accessed: 15.12.2017]

Anonymous. 2014. http://www.yesildunya.net [Accessed: 17.12.2017]

Anonymous. 2016a. TUIK. Available from: http://www.tuik.gov.tr/UstMenu.do?metod=temelist. [Accessed: 17.12.2017]

Anonymous. 2016b. Food and Agriculture Organization of the United Nations Available from: http://faostat3.fao.org/ browse/Q/*/E. [Accessed: 17.12.2017]

Gül A, Tüzel İH, Tuncay Ö, İrget ME, Eltez R.Z and Düzyaman E. 1998. Investigations on the effects of open and closed systems on plant growth, yield, water and fertilizer usage in greenhouse cucumber growing with bag culture. Project of Tübitak TOGTAG 1512, Izmir.

Pezikoğlu F. 1999. Greenhouse vegetable breeding and issues. Ministry of Agriculture, Agriculture and Village Magazine, No: 128.

Sevgican A. 1999. Greenhouse olericulture (Soilless Farming). Ege Univ. Agricultural Faculty Publications, Bornova, İzmir, No: 526

Tüzel Y, Özçelik A. 2004. Recent trends and developments in protected cultivation of Turkey. International Workshop on "La Produzione in serradopol'era del bromurodi metile". Catania-Italy, 1-3 April. Pp: 189-198.

Van Os EA, Wohanka W, Bruinsand M, Seidal R. 2000. Slow filtration: A technique to minimise the risks of spreading root-infecting pathogens in closed hydroponic systems. Int. Sym. On Protected Cultivation in Mild Winter Climates: Current Trends for Sustainable Technologies, 495-502. 